\title{
Brostið stuðningsnet útskrifta
}

Í góðu heilbrigðiskerfi fá sjúklingar viðeigandi pjónustu á réttum tíma og á peim stað par sem hagkvæmast er að veita hana. Önnur mynd blasir víða við okkur í daglegum störfum í heilbrigðispjónustunni. Örlítið brot af peim raunveruleika nær athygli fjölmiðla í gegnum fréttalýsingar á yfirfullri bráðamóttöku Landspítala eða löngum biðtíma eftir hjúkrunarrýmum. Á bakvið tjöldin kraumar alvarlegur mönnunarvandi sem er flókið að horfast í augu við.

Tafir í útskriftum eru ekki séríslenskt fyrirbæri. Í öðrum löndum pykir pað áskorun ef í 8-10\% af rúmum sjúkrahúsa eru einstaklingar sem bíða útskriftarúrræða. ${ }^{1}$ Á Landspítala er hlutfallið tvöfalt hærra pegar einungis er horft til hóps sem bíður útskriftar á hjúkrunarheimili. ${ }^{2}$ Írska öldrunarfræðafélagið birti fyrr á pessu ári leiðarvísi sem tekur á peim áskorunum sem tafir á útskriftum aldraðra leiða af sér fyrir samfélagið. ${ }^{3}$ Írar hafa valið að nota hugtakið „,brostið stuðningsnet útskrifta“" (discharge support failure) sem ber ekki ásökunartón gagnvart polendum í pessum kringumstæðum. Petta er lausnamiðaðra en hugtakið fráflæðisvandi og dregur fram í dagsljósið alvarleika pess að veita viðkvæmasta sjúklingahópnum ófullnægjandi pjónustu til að leysa plássvanda.

Pegar fjölveikir aldraðir eða hrumir einstaklingar dvelja á bráðasjúkrahúsi lengur en nauðsynlegt er aukast líkur á ótímabærum dauða, færniskerðingu, spítalasýkingum og aukaverkunum tengdum lyfjameðferð. Einstaklingarnir lifa í óvissu, einangrast félagslega og einkenni punglyndis og kvíða verða algengari. •að myndast mikil pressa á að útskrifa og starfsanda hrakar sem bætir enn frekar á hringekju uppsafnaðs vanda. ${ }^{4}$

Í pessu hefti Læknablaðsins ${ }^{5}$ birtist áhugaverð grein sem ber saman heilsufar og lifun íbúa hjúkrunarheimila fyrir og eftir reglugerðarbreytingu sem tók gildi 2007 með strangari skilyrðum fyrir flutningi inn á hjúkrunarheimili. Íbúar eru almennt veikari, flytjast oftar beint af sjúkrahúsi og lifun er styttri eftir reglugerðarbreytinguna pó margir aðrir pættir geti einnig haft áhrif á pessa próun. Greinin beinir einnig sjónum að pungri sjúkdómsbyrði, færniskerðingu og vaxandi pörf fyrir einkennameðferð sem hjúkrunarheimili purfa að takast á við. Sterkustu áhættupættirnir fyrir dauðsfalli innan tveggja ára frá flutningi á hjúkrunarheimili voru sjúkdómsgreiningarnar hjartabilun og langvinn lungnateppa. Hlutfall íbúa með greiningu Alzheimer-sjúkdóms fer hækkandi en einstaklingar með pessa greiningu voru ólíklegri til að deyja innan tveggja ára. Pessar sviðsmyndir minna á mikilvægi teymispjónustu faghópa í starfi hjúkrunarheimila. Pekkingargrunnur og verkferlar öldrunarlækninga eru mikilvægir pættir í pjónustu hjúkrunarheimila en ábyrgð og hlutverk lækna í pjónustu hjúkrunarheimila hefur verið illa skilgreint opinberlega á Íslandi. ${ }^{5}$ Flutningur í hættulegt og framandi umhverfi bráđasjúkrahúsa er íbúum hjúkrunarheimila sjaldan til góðs. Meðferð lungnabólgu, lífslokameðferð og atferlistruflanir tengdar heilabilunarsjúkdómum eru dæmi um kringumstæður par sem einstaklingum farnast betur á heimilinu ef viðeigandi pekking er til staðar. ${ }^{6}$ Varðandi heilabilunarsjúkdóma má nefna að RAI-matstækið sem styður við fjármögnun hjúkrunarrýma hefur verið gagnrýnt fyrir að mæla ekki á sanngjarnan hátt einkenni heilabilunar og draga úr hvata heimila til að taka við einstaklingum með erfiðari atferlistruflanir sem oft bíða of lengi eftir plássi.

Kortlagning á peim páttum sem hafa forspárgildi varðandi dvalartíma (lifun) í hjúkrunarrýmum gefur einnig tilefni til að beina sjónum út fyrir veggi hjúkrunarheimila. Í pví samhengi má ekki gleymast að meirihluti aldraðra býr sjálfstætt til æviloka. Ströng skilyrði fyrir flutningi á hjúkrunarheimili og forgangur peirra sem hafa beðið lengi á sjúkrahúsi eru við fyrstu sýn ekki óeðlileg forgangsröðun. Hins vegar er sú spurning orðin áleitin hvort afgerandi forgangur sjúkrahúsa að hjúkrunarrýmum án pess að aðrar grunnstoðir séu styrktar sé rétta leiðin. Í kanadískri rannsókn voru skoðaðar ástæður pess að ekki tókst að útskrifa einstaklinga sem höfðu ekki lengur pörf fyrir áframhaldandi sjúkrahúsdvöl. Meginniðurstöður voru pær að á sjúkrahúsum væri innbyggð tregða til útskrifta í heimahús og að margir sem liggja á sjúkrahúsum og lenda á biðlista eftir hjúkrunarrými hefðu getað útskrifast heim með viðeigandi stuðningsneti. ${ }^{4}$

Fjölveikindi og færniskerðing eru algengustu ástæður innlagna á sjúkrahús. Pjónusta til stuðnings búsetu heima og verkferlar bráđasjúkrahúsa parfnast skipulags samkvæmt pessum raunveruleika. Pó tölfræði gefi til kynna að margt sé vel gert í íslensku heilbrigðiskerfi eru pví miður margar vísbendingar um að fjölveiku öldruðu fólki sé ekki vel sinnt. Engin af meginstoðum heilbrigðispjónustunnar hefur minna vægi en önnur pegar ráðist er að rót vandans. Heimapjónusta, heilsugæsla, sjúkrahús og hjúkrunarheimili purfa ásamt stjórnvöldum að vinna heildstætt saman í takt við lýðfræðilega próun.

\section{Heimildir}

1. Rojas-García A, Turner S, Pizzo E, Hudson E, Thomas J, Raine R. Impact and experiences of delayed discharge: a mixed-studies systematic review. Health Expect 2018; 21: 41-56.

2. Embætti landlæknis. Hjúkrunarrými á Íslandi - biðlistar, biðtími, lengd búsetu og uppbygging. Ársuppgjör 2018. 2019.

3. The Irish Gerontological Society. Position Paper. Addressing the Challenge of Delayed Discharges from Hospitals. May 2019.

4. Bender D, Holyoke P. Why some patients who do not need hospitalization cannot leave: A case study of reviews in 6 Canadian hospitals. Healthc Manage Forum 2018; 31: 121-5.

5. Hjaltadóttir I, Ólafsson K, Sigurðardóttir ÁK, Arnardóttir RH. Heilsa og lifun íbúa fyrir og eftir setningu strangari skilyrða fyrir flutningi á hjúkrunarheimili 2007. Læknablaðið 2019; 105: 435-41.

6. Hansdóttir $H$, Jónsson JE. Verksvið læknisins á hjúkrunarheimili. Læknablaðið 2009; 95: 187-92.

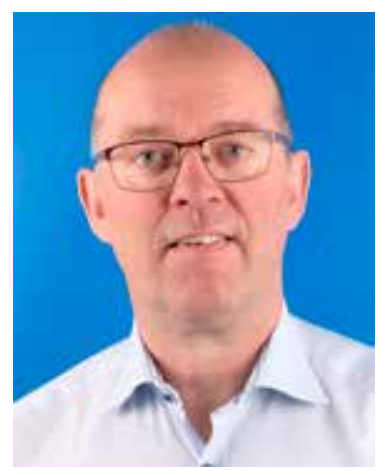

\section{Aðalsteinn Guðmundsson}

sérfræðingur í almennum lyf- og öldrunarlækningum klínískur dósent í læknadeild HÍ, formaður Iyfjanefndar Landspítala

adalstg@landspitali.is

\section{Discharge Support Failure}

Adalsteinn Gudmundsson MD Clinical Associate Professor, Faculty of Medicine, University of Iceland. Chairman of the Drugs and Therapeutics Committee, Landspitali University Hospital

DOI: 10.17992/lbl.2019.10.248 